\title{
A questão regional no pensamento de Antonio Gramsci e Celso Furtado
}

\section{Laurindo Mékie Pereira}

O objeto deste texto é o entendimento da chamada questão regional no pensamento de dois pensadores do século XX: o italiano Antonio Gramsci e o brasileiro Celso Furtado. Os dois autores representam duas vertentes de interpretação para uma mesma temática e foram referências importantes para o estudo e mesmo enfrentamento, respectivamente, da Questão Meridional na Itália e da Questão Nordeste no Brasil.

Evidentemente, em função da amplitude da bibliografia produzida pelos autores, bem como da que foi escrita a respeito deles e da diversidade de temas que emerge desse conjunto, o presente enfoque fará recortes, concentrando-se apenas na temática proposta e só abordando outros temas e conceitos quando eles se apresentarem imprescindíveis à compreensão do objeto em análise.

Antonio Gramsci nasceu na Sardenha, sul da Itália, no ano de 1891. Desde sua juventude foi um ativo participante das lutas políticas, tendo militado no Partido Socialista Italiano - PSI - e no Partido Comunista Italiano - PCI, fundado em 1921. Em 1926, ele foi preso pela polícia de Mussolini. Escreveu na prisão os famosos quaderni ${ }^{1}$, onde estão contidas suas concepções teóricas e políticas. Gramsci passou vinte anos na prisão, sendo libertado em abril de 1937, poucos dias antes de sua morte. ${ }^{2}$

Celso Furtado nasceu em Pombal, no sertão do Estado da Paraíba, no ano de 1920. Formou-se em Direito. Participou da Força Expedicionária Brasileira na II Guerra Mundial. Concluiu o Doutorado em Economia pela Universidade de Paris (Sorbonne), em 1948. Entre 1949 e 1957, trabalhou na Comissão Econômica para América Latina e Caribe - CEPAL, tornando-se um dos expoentes do que se convencionou chamar pensamento cepalino. Planejou e dirigiu, de 1959 a 1963, a Superintendência de Desenvolvimento do Nordeste - SUDENE. Furtado escreveu dezenas de livros. ${ }^{3}$ A questão nordeste foi objeto constante de suas preocupações, principalmente nos textos Uma politica de desenvolvimento econômico para o Nordeste e A operação Nordeste. ${ }^{4}$ Celso Furtado, o "homem de ação e militante do desenvolvimentismo" , conforme expressōes de Ricardo Bielschowsky, faleceu em novembro de 2004.

A discussão do problema regional reúne os dois pensadores. A vinculação de ambos com suas regiões de origem parece informar boa parte de suas formulações teóricas e ações políticas. Em alguns aspectos, os autores se aproximam. Em muitos outros, se diferenciam nitidamente.

Neste texto, procede-se primeiro ao exame da questão regional - meridional e nordestina - no pensamento de cada um dos autores; em seguida, discutem-se os elementos que aproximam os dois intelectuais e, ao final, os aspectos que os diferenciam.

\section{Antonio Gramsci}

Antes da prisão, Gramsci redigiu pequenos textos acerca da "Questão Meridional" para a imprensa. Em 1926, ele produziu um texto intitulado "Alguns temas da Questão Meridional”, texto clássico que ficou inacabado em virtude de sua prisão, em fins de setembro do mesmo ano. Os escritos "jornalísticos" e o "Alguns temas" foram reunidos no livro A Questão Meridional.

Os problemas do Mezzogiorno tinham grande relevância para o cidadão e intelectual Antonio Gramsci. A história, as tradições, o passado, diz o próprio Gramsci, pesam muito na forma como pensa e age o intelectual, por isso "[...] considerar como possível que ele possa [...] romper com todo o passado para se colocar completamente no terreno de uma nova ideologia é absurdo."

A formação juvenil de Gramsci foi controvertida, explica Carlos Nelson Coutinho. Elementos como a influência idealista de Benedito Croce marcariam o autor. Os problemas do Mezzogiorno torna- 
ram-se prioridades na agenda do PCI por influência de Gramsci. Saliente-se que, para ambos os temas - a influência idealista e o "meridionalismo" -, Gramsci foi capaz de dar uma resposta dentro dos marcos do materialismo histórico, é certo que a este ampliando de forma considerável. ${ }^{8}$

Ainda jovem, Gramsci aderiu a uma campanha antiprotecionista que reunia intelectuais do Mezzogiorno. Por essa ocasião, 1910-1913, tornou-se, então, decididamente defensor do livre-cambismo e partidário de um pensamento regionalista, meridionalista. A oposição ao protecionismo tinha uma razão de ser. A política protecionista era elemento constitutivo do "bloco conservador", que reunia os industriais do norte e os latifundiários do sul, mantendo excluídos os camponeses. ${ }^{9}$

Em 1926, Gramsci dedicou-se à reflexão mais detida sobre a questão meridional.

A Questão Meridional é como um diamante de mil facetas, onde cada uma, iluminando um ponto particular, focaliza um dos aspectos do pensamento teórico-político de Gramsci, com um brilho e uma tal transparência que, posteriormente, bastará a Gramsci retomar o conjunto desses temas abordados em 1926, para desenvolvê-los de forma unitária nos Cadernos. ${ }^{10}$

A metáfora utilizada por Macciocchi para se referir ao alcance do livro A Questão Meridional, é adequada. De fato, linhas mestras do pensamento de Gramsci, como as noções de "bloco histórico", "hegemonia”, o papel dos intelectuais e a aliança operário-camponesa, já estão presentes no texto de 1926.

As desigualdades norte-sul, na Itália, datam do século XIX. Desde então, floresceu no norte uma sociedade urbana e industrial, enquanto, no sul, a economia permaneceu rural, com forte concentração fundiária e intensa exploração dos camponeses. As raízes dessa estrutura podem ser buscadas na forma como se deu a unificação italiana na segunda metade do século XIX. Foi a natureza conservadora da "revolução italiana" - a "revolução passiva" - que produziu as duas Itálias. ${ }^{11}$ Não se deve pensar, todavia, que as "duas Itálias" estivessem separadas; pelo contrário, são as relaçôes estabelecidas entre as elites industriais do norte e os latifundiários do sul que explicam, em boa medida, a sobrevivência desse "modelo". Em outros termos, a desigualdade era a forma de desenvolvimento capitalista no país.

Gramsci não foi o primeiro a abordar o problema meridional. Esse assunto era frequentemente discutido pelas lideranças políticas do norte e do próprio sul, mas sempre dentro de uma perspectiva reformista e regionalista. O que Gramsci fez foi colocar o problema em termos revolucionários, "classista" e nacional.

A sociedade meridional, segundo o autor, era um grande "bloco agrário", formado por três estratos sociais: os camponeses, massa desorganizada; os intelectuais da pequena e média burguesia rural; e os grandes proprietários de terras/grandes intelectuais. ${ }^{12}$

Os camponeses estavam em constante "efervescência", mas eram incapazes de se expressar de forma organizada e duradoura. Os grandes proprietários estavam ligados às indústrias do norte, conformando o "bloco agrário-industrial": os primeiros apoiavam os segundos, em troca da manutenção dos latifúndios. As relações norte-sul eram, pois, estreitas: o sul funcionava como um mercado consumidor do norte e como reservatório de mão-de-obra. Além disso, as rendas dos latifundiários meridionais eram aplicadas nos bancos do norte, contribuindo para o desenvolvimento industrial dessa região. ${ }^{13}$

Definida, de forma geral, a situação do Mezzogiorno no âmbito político e econômico, resta discutir o "campo ideológico" ${ }^{14}$ do bloco agrário-industrial. É nesse âmbito que entra a inovadora contribuição de Gramsci quanto ao papel dos intelectuais.

A grande contribuição de Gramsci para o pensamento marxista, diz Hugues Portelli, está exatamente na sua explicação quanto às funções dos intelectuais. "O ponto fraco da relação estrutura-superestrutura, na teoria marxista, provinha de seu caráter puramente abstrato; ora, Gramsci fornece uma tradução concreta, social, desse vínculo orgânico: os intelectuais." ${ }^{15}$

Gramsci identifica dois tipos de intelectuais: o tradicional e o orgânico. ${ }^{16}$ Em A Questão Meridional, ele fala em "velho tipo de intelectual" e em "novo tipo de intelectual". O primeiro é o elemento organizador de uma sociedade camponesa e artesanal. Com o desenvolvimento da indústria, surgiu o segundo tipo, aquele "organizador técnico, o especialista em ciência aplicada", tipo predominante nas sociedades capitalistas. ${ }^{17}$ 
No sul da Itália, observa Gramsci, predomina o primeiro tipo, “[...] com todas as suas características: democrático na face camponesa, reacionário na face voltada para o grande proprietário e para o governo, politiqueiro, corrupto, desleal."18

Os intelectuais meridionais, explica o autor, derivavam de uma camada de pequenos e médios proprietários, viviam do aluguel da terra, da meação. Não eram camponeses, mas estavam próximos deles, interpunham-se entre eles e o grande proprietário. As duas faces desses intelectuais materializavam-se na sua capacidade de "receber os impulsos" dos camponeses e, ao mesmo tempo, discipliná-los dentro da ordem estabelecida, impedir que se colocasse em risco o bloco agrário industrial. A colaboração dos estratos médios, dos intelectuais, era parte da estrutura do bloco: em troca, o Estado lhes concedia empregos, privilégios econômicos, sociais e políticos. Assim, observa Macciocchi, profissionais liberais, advogados, professores, funcionários públicos, médicos, padres - todos intelectuais no sentido gramsciano - contribuíam para a manutenção do status quo no Mezzogiorno. ${ }^{19}$

Acima desses intelectuais pequenos, havia os grandes intelectuais, os "criadores", especialmente Benedito Croce. Há uma hierarquia entre os intelectuais, explica Hugues Portelli: "[...] na cúpula, [há] os criadores da nova concepção do mundo e de seus diversos ramos: ciência, filosofia, arte, direito, etc.; no escalão inferior, aqueles que estão encarregados de administrar ou divulgar essa ideologia." ${ }^{20}$ No caso do Mezzogiorno, Benedito Croce, o "intelectual criador", desempenhou o papel de aglutinador dos intelectuais pequenos, atraindo-os para o seu pensamento, para a ideologia burguesa nacional e europeia, afastando-os, por consequencia, das massas camponesas. ${ }^{21}$

Em termos sumários, são esses os dados gerais da Questão Meridional diagnosticados por Gramsci. O que fazer diante desse quadro?

As propostas dos intelectuais meridionalistas, da burguesia industrial e mesmo do Partido Socialista nunca ultrapassavam os limites do reformismo, haja vista a sua participação no bloco agrário industrial. Quanto aos camponeses, não conseguiam se expressar de forma organizada porque "seus" intelectuais estavam a serviço do Estado e dos grandes proprietários.

Para Gramsci, a solução da Questão Meridional era parte integrante da revolução socialista. Nesta, a aliança operário-camponesa desempenharia um papel central. Já em 1919, o autor dizia: “[...] o proletário setentrional, emancipando a si mesmo da escravidão capitalista, emancipará as massas camponesas meridionais subjugadas pelos bancos e pelo industrialismo parasitário do norte." 22 A ação do proletariado do norte em aliança com os camponeses do sul seria, pois, fundamental. No lugar do conflito "Região $x$ Região", entrava, portanto, o conflito operários-camponeses $x$ industriais-latifundiários-intelectuais de classe média.

Em 1926, Gramsci colocou a questão em termos mais claros e consistentes:

O proletariado pode se tornar classe dirigente e dominante na medida em que consegue criar um sistema de alianças de classes que lhe permita mobilizar contra o capitalismo e o Estado burguês a maioria da população trabalhadora - o que significa, na Itália, dadas as reais relações de classe existentes, que o proletariado pode se tornar classe dirigente e dominante na medida em que consegue obter o consenso das amplas massas camponesas. [...] Conquistar a maioria das massas camponesas, portanto, significa [...] compreender as exigências de classe que elas representam, incorporar essas exigências a seu programa revolucionário de transição, colocar essas exigências entre as suas reivindicações de luta. ${ }^{23}$

Essa passagem resume, de certa forma, o pensamento do autor sobre a questão. Note-se, em primeiro lugar, o papel de liderança do proletariado em sua aliança com os camponeses. Em segundo, embora Gramsci ainda não operasse com as categorias "sociedade civil" e "teoria ampliada do Estado" (sociedade civil + sociedade política), como observa Carlos Nelson Coutinho ${ }^{24}$, fica claro que a vitória "contra o capitalismo e o Estado burguês" somente se daria se o proletariado se tornasse classe "dirigente" e "dominante", o que significa, em termos gramscianos, conquistar, respectivamente, a hegemonia no plano da "sociedade civil" e o domínio da "sociedade política", dos aparelhos do Estado stricto sensu.

Quais eram os obstáculos para que isso ocorresse? O primeiro, observa o autor, era modificar a ideologia da classe proletária do norte quanto aos problemas do sul. Os "propagandistas da burguesia" haviam 
divulgado, no norte, a tese segundo a qual o sul era um "obstáculo ao desenvolvimento da Itália", e que seus habitantes eram "bárbaros e biologicamente inferiores". Assim, a culpa pelo atraso do sul seria imputada aos próprios meridionais e à "natureza", não estando relacionada a fatores históricos e sociais. ${ }^{25}$

Mais importante, porém, do que desconstruir esse discurso burguês, era o proletariado do norte se converter numa "classe nacional", acima de seus interesses específicos:

O metalúrgico, o carpinteiro, o operário da construção civil, etc. devem não só pensar como proletários e não mais como metalúrgico, carpinteiro, operário da construção, etc., mas devem ainda dar um passo à frente: devem pensar como membros de uma classe que tende a dirigir os camponeses e os intelectuais, de uma classe que só pode vencer e construir o socialismo se auxiliada e seguida pela grande maioria dos estratos sociais. ${ }^{26}$

Não se tratava de um obstáculo simples. Como salienta Maria-Antonietta Macciocchi, havia se desenvolvido, no norte, sob a orientação do Partido Socialista, uma classe operária corporativista que, em última análise, também se beneficiava do bloco agrário-industrial, e, portanto, da exploração dos camponeses. A autora alarga o entendimento do problema para além da Itália e mostra como o "elitismo operário", o "corporativismo sindical", dividia os trabalhadores em toda a Europa, especialmente entre imigrantes e "nativos" e, por isso, funcionava como freio às ações revolucionárias. ${ }^{27}$

Nas últimas páginas do seu texto, Gramsci ressalta a necessidade de intelectuais para desagregar o bloco agrário-industrial ou, em termos similares, desagregar o bloco intelectual que lhe dava unidade e coerência. Assim, para lutar contra a ideologia burguesa difundida no norte e se converter numa "classe nacional" revolucionária, o proletariado, em aliança com os camponeses, teria de ter seus intelectuais próprios, o que era algo muito difícil, reconhecia Gramsci: "O proletariado, como classe, é pobre de elementos organizativos, não tem e nem pode formar um estrato próprio de intelectuais, a não ser muito lentamente, muito arduamente e apenas depois da conquista do poder estatal." ${ }^{28}$ Em consequencia, o desafio que se colocava era "desagregar o bloco intelectual", condição básica para destruição do bloco agrário-industrial e, por fim, resolver a questão meridional.

Embora o texto de Gramsci ficasse inacabado, em virtude de sua prisão, as linhas mestras do seu entendimento da Questão Meridional ficaram claras: o diagnóstico feito, tendo em perspectiva as relações de classe, é coerente com a solução proposta nos termos de uma revolução socialista, sob a hegemonia do proletariado, em aliança com os camponeses do sul.

As discussões de Gramsci acerca da questão meridional só foram publicadas em 1930, e mesmo a difusão de sua obra (os Cadernos do Cárcere) só ocorreu na Europa após a Segunda Guerra. ${ }^{29}$

A influência do pensamento de Gramsci e especificamente de suas reflexões acerca do Mezzogiorno seria muito grande, por diversos motivos: a) pelo seu alcance teórico, b) pela permanência, embora com modificações, da "questão meridional" e c) especialmente pela dimensão europeia do tema. Para Macciocchi, o livro de Gramsci ultrapassa as fronteiras da Itália e o seu tempo cronológico (1926: redação, 1930: publicação) porque se trata de uma "[...] análise modelo da estrutura de classes, uma estratégia revolucionária, passando pela aliança entre cidade e campo, entre operários, camponeses e intelectuais [...] no interior de uma sociedade industrialmente desenvolvida." ${ }^{30}$

Esses seriam os méritos/contribuições de "A Questão Meridional" quanto ao método. A "metodologia” gramsciana seria duplamente importante, pois: a) serviria como instrumental analítico/modelo para se pensar a revolução nas "sociedades industriais desenvolvidas" e b) seria útil para se compreender problemas similares em toda a Europa porque

Gramsci aborda o problema meridional, por um lado como problema nacional, por outro lado, em sua relação com o desenvolvimento internacional do capitalismo na Europa, caracterizado pela dominação, pelas zonas superindustrializadas das ilhotas de subdesenvolvimento $[\ldots] .^{31}$

No Brasil, a difusão do pensamento de Gramsci teve de esperar os anos 1960-1970, extrapolando, na década de 1980, o âmbito acadêmico e partidário, para ser absorvido também por parte da gran- 
de imprensa. ${ }^{32}$ As semelhanças entre a "Questão Meridional” e a "Questão Nordeste" tornam Gramsci ainda mais interessante para o Brasil. Sua influência na interpretação do tema é visível, por exemplo, na obra de Rosa Maria Godoy Silveira (1984) e na de Iná Elias de Castro (1992). ${ }^{33}$

Antes, porém, das ideias de Gramsci se difundirem no Brasil, a chamada questão nordeste já havia sido objeto de uma extensa discussão teórica e política. No olho desse furacão estava o economista Celso Furtado, a um só tempo, o teórico e executor da política de desenvolvimento para o nordeste.

\section{Celso Furtado}

O autor tratou do tema nordeste em várias de suas obras ${ }^{34}$, mas foi nos textos Uma politica de desenvolvimento econômico para o Nordeste e A operação Nordeste que tratou especificamente do assunto e foram estes que fundamentaram o projeto SUDENE. Assim, privilegia-se aqui o exame da questão regional no pensamento de Furtado tomando como referências principais esses dois livros.

A primeira observação que se pode fazer quanto ao documento Uma politica de desenvolvimento econômico para o Nordeste é o caráter articulado de suas ideias, tanto no diagnóstico quanto nas propostas de ação. Coeso, apoiado em dados estatísticos e bem estruturado, o texto é muito convincente. Não por acaso, esse documento exerceu grande influência em todo o debate subsequente acerca do nordeste.

Embora o texto Uma política tenha sido apresentado como um trabalho técnico para diminuir possíveis reações políticas, seu conteúdo é também marcadamente político, como se pode ver logo na primeira página: "A disparidade de níveis de renda existente entre o Nordeste e o Centro-Sul do país constitui, sem lugar à dúvida, o mais grave problema a enfrentar na etapa presente do desenvolvimento econômico nacional." 35

Estabelecer essa premissa significa afirmar que o problema do nordeste seria não apenas uma questão de interesse nacional, mas também a questão mais importante do país no plano econômico. Compreender essa complexa relação entre o regional e o nacional (e mesmo a relação dessas duas instâncias com o internacional) é imprescindível para a problemática aqui escolhida. A ideia de nação/nacionalidade ocupa importante espaço nas reflexões de Furtado. Assim, suas teses acerca do regional dificilmente poderão ser descoladas daquela ideia maior. ${ }^{36}$

Do ponto de vista econômico, o texto não aponta a resolução dos problemas do nordeste como indispensáveis ao crescimento do país. Claro está que, até o momento (1959), o nordeste desempenhou um papel fundamental como gerador de divisas, em sua maior parte utilizada pelo centro-sul no seu processo de industrialização. Não sendo uma necessidade econômica, por que o nordeste seria tão importante para a "nação"? A resposta é que: "A persistirem as tendências atuais, há o risco real de que se diferenciem cada vez mais os dois sistemas econômicos já existentes no território nacional, e de que surjam áreas de antagonismo nas relações entre os mesmos." ${ }^{37}$ Nesse trecho aparecem: a) a concepção dualista da economia brasileira e b) a noção de conflito região $x$ região.

Acerca da primeira ideia, Celso Furtado explica que, embora "articuladas", as economias do nordeste e do centro-sul não constituem um sistema econômico. A segunda, em virtude da diversificação do seu parque industrial, "[...] encontra-se em condiçōes de poder apoiar-se em si mesma para crescer." ${ }^{38} \mathrm{Ou}-$ tra era a situação no nordeste.

Esse trecho da argumentação de Furtado é interessante porque, embora não compreenda a relação dialética entre nordeste e sudeste - o desenvolvimento desigual e combinado do capitalismo - o autor não aponta o "setor atrasado" da economia brasileira - o NE, no caso - como "obstáculo ao desenvolvimento do país"; pelo contrário, deixa claro que o centro-sul pode se desenvolver "sozinho". Parece que é de novo a questão nacional que está presente. Para Furtado, o desenvolvimento do centro-sul, na qualidade de uma região, não tem sentido se a nação, como um todo, não estiver acompanhando tal ritmo. $\mathrm{O}$ desenvolvimento integrado das regiōes era, para o autor, condição para a existência e continuidade da nação.

Embora não fosse um obstáculo econômico ao desenvolvimento do centro-sul, o nordeste era, para Furtado, um obstáculo à sobrevivência da "integridade nacional". Para o autor, a intensa migração 
de trabalhadores nordestinos para o centro-sul tenderia a rebaixar os salários na região receptora, o que provocaria dois efeitos negativos: diminuiria a renda dos trabalhadores e não estimularia a modernização (uma vez que esta advém da necessidade de diminuir os custos com a mão-de-obra). Se não se atacasse o problema nordestino para "reter" lá os seus trabalhadores, poderia ocorrer uma "[...] aliança das organizações sindicais e patronais das zonas mais desenvolvidas, com o objetivo de conquistar e defender mais altos salários, dificultando a absorção de novos contingentes de mão-de-obra." ${ }^{39}$ Falando para um público, em sua maioria, composto por militares, Furtado não hesitava: "Se tal fenômeno vier a ocorrer no Brasil, país de grande extensão geográfica, a formação de grupos regionais antagônicos poderá ameaçar a maior conquista de nosso passado: a unidade nacional." ${ }^{40}$ Convém notar que, quando se dirige aos militares, para os quais a ideia de "nação" é sabidamente fundamental, Furtado era ainda mais enfático no item "risco à integridade nacional" do que no texto do GTDN. Isso significa que, além de ser parte do próprio pensamento de Furtado, a preocupação com a nação era, também, um trunfo político importante, haja vista a batalha política em que se transformou a criação da SUDENE. ${ }^{41}$

Assim, a primeira "providência" do documento Uma política foi dar ao "problema nordeste" uma dimensão nacional.

Acerca da relação econômica stricto sensu, entre o nordeste e o centro-sul, o texto do GTDN dividese em duas partes: quando faz o diagnóstico da situação nordestina, identifica, claramente, como as relações com o centro-sul teriam sido nefastas para os nordestinos; porém, quando aponta as "soluções", seu "plano de ação", a relação com o restante do país pouco aparece. Em certas passagens, o nordeste é tratado como se fosse um "país". ${ }^{2}$

O atraso do nordeste em relação ao centro-sul seria devido, em princípio, à "escassez relativa de terras aráveis, inadequada precipitação pluviométrica, grande concentração da renda na economia açucareira, predomínio do setor de subsistência na pecuária do hinterland semi-árido". ${ }^{43}$ No entanto, a essas "causas primeiras" vêm se somar outras relacionadas à política de desenvolvimento do país. Esta teria prejudicado o nordeste - embora não intencionalmente, observa Furtado - nos itens política cambial e controle seletivo das importações.

Segundo o texto, a balança comercial do nordeste teve um saldo positivo de 638 milhões de dólares no período 1948-1956, valor suficiente para cobrir o déficit da balança comercial do resto do país que foi de 552 milhões de dólares. Feitas as contas ainda sobrariam 71 milhões de dólares. ${ }^{44}$ E por que o nordeste ${ }^{45}$ não se utilizava dessas divisas? O problema é que o Governo Federal, após um período de baixa taxa cambial, entre 1945 e 1948 - o que facilitou as importações e logo esgotou as reservas brasileiras ${ }^{46}$ - "foi obrigado" a adotar um regime de discriminação das importações, favorecendo a importação de bens-de-capital. Quando se examina a pauta de importaçôes, vê-se que a maior parte desses importados destinava-se ao centro-sul. Qual a razão disso?

[Porque] investir em equipamento significava vantagem real, porque o bem-de-capital era barato. Daí resultou que, onde o salário era mais alto, o benefício auferido também era maior. Como os salários no centrosul eram mais altos que no nordeste, era vantajoso concentrar o investimento naquela região do país. ${ }^{47}$

O autor registra também outros fatores, como o comércio NE-centro-sul, em que se observava uma balança comercial desfavorável ao primeiro. É uma típica análise cepalina ${ }^{48}$ da relação centro-periferia: o NE compraria manufaturados do centro-sul e venderia matérias-primas para este.

Assim sendo, observa o texto, houve uma transferência de renda no sentido nordeste-centro-sul, contribuindo para o desenvolvimento do segundo e, evidentemente, para o agravamento das disparidades. ${ }^{49}$ Portanto, note-se, novamente, que o nordeste, nesses textos de Furtado, contribuiu para o desenvolvimento do centro-sul (e do país). ${ }^{50}$

Se na análise das causas do atraso relativo do nordeste em relação ao centro-sul, Celso Furtado pensa o regional em suas estreitas relações com o nacional, quando parte para as propostas, ele concentra-se no regional, isolando-o, de certa forma, do todo nacional. 
As quatro diretrizes básicas do Plano de Ação eram:

"criar no Nordeste um centro autônomo de expansão manufatureira";

"transformação da economia agrícola da faixa úmida, com vistas a proporcionar uma oferta adequada de alimentos nos centros urbanos, cuja industrialização deverá ser intensificada”;

"transformação progressiva da economia das zonas semi-áridas no sentido de elevar sua produtividade e torná-la mais resistente ao impacto das secas";

"deslocamento da fronteira agrícola do Nordeste, visando incorporar à economia da região as terras úmidas do hinterland maranhense [...]" ${ }^{51}$

Interessa, para a presente discussão, observar o aspecto regional nas diretrizes. A primeira diretriz é, nesse aspecto, reveladora. É bastante divulgada a importância dada pelo GTDN à industrialização, fruto da aplicação dos princípios da CEPAL no enfrentamento do "problema nordeste". De fato, o documento Uma política menciona a industrialização como "única" estratégia para o desenvolvimento do nordeste. Entretanto, grande parte da crítica a esse "industrialismo" 52 é inadequada, pois confunde o documento do GTDN com as ações da SUDENE ou não capta o caráter integrado das propostas do GTDN. As medidas entrelaçam-se como se pode ver facilmente, observando-se as diretrizes do Plano de Ação: a diretriz "b" é indissociável da "a"; já a reorganização da economia do semi-árido (diretriz "c") implicava liberação de contingente populacional dessa região, a ser absorvido na colonização do Maranhão (diretriz "d") que, por sua vez, também produziria alimentos para os centros urbanos e mesmo para o meio rural onde os alimentos fossem escassos. Assim, embora a industrialização fosse apontada como "imprescindível ao desenvolvimento", não é possível dizer que o GTDN acreditasse na indústria como estratégia de solução de todos os problemas e ignorasse outros setores, como a agricultura, porque: "O objetivo central do presente Plano de Ação é [...] tentar modificar o curso dos acontecimentos, pelo ataque simultâneo em um conjunto de frentes consideradas vitais." ${ }^{\prime 3}$ (grifos meus).

Retomando a relação do regional com o nacional. Conforme o GTDN, a política de industrialização tinha três objetivos básicos: a) "dar emprego a essa massa de população flutuante", b) "criar uma classe dirigente nova, imbuída do espírito de desenvolvimento" e c) "fixar na região os capitais formados em outras atividades econômicas, que atualmente tendem a emigrar." ${ }^{4}$

Gerar empregos no nordeste ${ }^{55}$, não só na indústria, significava impedir a migração para o centro-sul, o que era tido como um dado fundamental na relação nordeste-centro-sul. Em última análise, seria esse problema que geraria conflitos inter-regionais e colocaria em risco "a unidade nacional".

O regional aparece também nos objetivos "b" e "c" em que fica clara a intenção de se "desenvolver" o nordeste de forma endógena. A ação do Estado deveria suscitar uma nova classe na região, os capitais eram formados na região e nesta deveriam permanecer. ${ }^{56}$ Nessa passagem, Celso Furtado parece ignorar o restante do país e desconsiderar o fato de que a economia nordestina era parte de um conjunto maior e que, alterar aquela, sem considerar este, era, economicamente, praticamente impossível, como apontariam vários autores, já nos anos 60 e posteriormente. ${ }^{57}$

A importância do regional na industrialização é também visível quando se analisa o tipo de indústria a ser estimulada, a saber, aquela que aproveitasse as matérias-primas da região, o mercado regional e absorvesse mão-de-obra regional. Evidentemente, Celso Furtado não ignorava que a indústria nordestina sofreria a concorrência do centro-sul, por isso a ênfase na exploração dos fatores como a abundante mão-de-obra, que daria à indústria local vantagens comparativas às de outras regiōes. Além disso, havia a preocupação de que as indústrias a serem estimuladas tivessem em perspectiva, além do mercado regional, a capacidade de concorrência e expansão no mercado nacional, caso da indústria de cimento. Aqui se revela outro dado do problema região x nação: como o desenvolvimento da primeira é o que está em foco, a segunda aparece como "passiva" no processo. Isto é, analisa-se e propóe-se o aproveitamento do potencial do mercado nacional pelo nordeste, mas não o inverso (pelo menos não explicitamente). Há, pois, a ideia de que a região deveria ser explorada/desenvolvida "endogenamente". 
A reorganização do semi-árido e a colonização do Maranhão (diretrizes "c" e "d") eram faces de uma mesma moeda. Até então, o Maranhão não era "nordeste". Celso Furtado propôs a sua inclusão na "regiāo" a ser assistida pela SUDENE. Esse Estado desempenharia o duplo papel de receptor dos excedentes demográficos (a serem liberados com a reorganização do semi-árido) e de produtor de alimentos. Mas por que era necessário transformar o Maranhão em nordeste?

Celso Furtado havia advogado a inclusão desse Estado na área das secas não porque de fato ele fosse sujeito à seca, mas para calar os protestos resultantes da migração planejada para fora. Como parte da área das secas, a colonização do Maranhão seria então um processo de migração interna, uma noção politicamente atraente. ${ }^{58}$

Se Sílvio Maranhão está certo, pode-se dizer que: a) o regionalismo era uma ideia forte no debate político nordestino, daí a resistência às propostas de migração "para fora"; b) Celso Furtado estava consciente de que tinha que lidar com essa variável no processo de implantação da SUDENE; c) o regionalismo de Furtado não era o mesmo das lideranças políticas ${ }^{59}$ que se oporiam à migração "para fora"; e d) ao propor (e conseguir) transformar, por decreto, o Maranhão em nordeste, Furtado demonstra que sua concepção de região não é rígida, nem embasada em mitos e/ou ideologias manipuladoras. A "escolha" do Maranhão para ser "nordeste" não se baseou em possíveis semelhanças culturais ou políticas: "Podemos fazer crescer o nordeste. Podemos incorporar ao nordeste precisamente aquilo que lhe falta: terras úmidas, terras com invernos regulares." "Em nosso esquema, o Maranhão é uma peça fundamental, porque absorve gente e produz mais alimentos." ${ }^{\prime 0}$ É um trecho revelador de agudo pragmatismo em Furtado: seu projeto era resolver os problemas sociais que se manifestavam no nordeste. A regiāo subordina-se a esse objetivo.

Sumarizando as linhas gerais da problemática regional $\mathrm{x}$ nacional nos dois documentos citados, pode-se ver que, para Furtado, o nordeste não obstava ao desenvolvimento do centro-sul, pelo contrário, contribuía para isso. Furtado afirma também que, naquele momento (1959), o centro-sul tenderia a se desenvolver "sozinho". Por que, então, o nordeste era apresentado como o maior problema do país? Porque o agravamento das disparidades poderia colocar em risco a "unidade nacional" e comprometer o projeto de nação.

Assim, a ênfase dada ao regional, principalmente no item "plano de ação", não equivale à sobreposição do regional ao nacional. Uma análise cuidadosa da questão revela que Furtado estava pensando, em última análise, no "país", pois a política de desenvolvimento do nordeste, embora com tintas regionalistas, implicava gastos do erário nacional e, como aponta o GTDN, o poder público já transferia para o nordeste cifras semelhantes àquelas que eram transferidas (no plano privado) para o centro-sul, em virtude da política cambial e de importações e do comércio inter-regional. Então, o que era necessário, nessa visão, era tornar o investimento público, na região, produtivo, de forma a reformular a economia (e também as relações sociais e políticas) para torná-la resistente às secas. Ao fazer isso, resolver-se-ia, segundo o autor, o problema do nordeste e do país, uma vez que sua unidade não seria mais afetada pela migração de excedentes de mão-de-obra. Resultado: não haveria mais risco para a unidade nacional, já que o crescimento planejado das regiōes diversas impediria a eclosão de animosidades inter-regionais.

As preocupações de Furtado são coerentes com o pensamento cepalino que as inspirava. Eram mais políticas do que econômicas, stricto sensu. Para ele, a "nação" só é possível se todas as regiōes estiverem se desenvolvendo de forma minimamente equilibrada. Sendo o nordeste o caso mais grave, urgiria enfrentá-lo. E isso seria um "dever nacional”, uma vez que o nordeste muito contribuiu para o desenvolvimento do país, especialmente o do centro-sul. Assim, em última instância, a causa de Furtado é nacional, só que, para resolver esta, tem-se de atacar o problema regional.

Para diversos autores, particularmente nos anos 1970, o pensamento nacionalista-desenvolvimentista, a teoria do subdesenvolvimento de Furtado, foi “[...] a ideologia própria do chamado período populista; se ela hoje não cumpre esse papel, é porque a hegemonia de uma classe se afirmou de tal modo que a face já não precisa de máscara." ${ }^{61}$ Nessa crítica, fundamentalmente, repele-se a questão regional e nacional enfatizada por Furtado e pela CEPAL em virtude do encobrimento das relações de classe que ela provoca. ${ }^{62}$ 
Quando se examina o texto do GTDN e o de $A$ Operação Nordeste nota-se, de fato, uma preocupação excessiva com a regiāo, categoria generalizadora, que mascara as clivagens sociais. A primeira demonstração disso está na frase que abre o documento Uma política, em que se diz que o maior problema do país é a disparidade de renda "entre o Nordeste e o Centro-Sul". À categoria região acopla-se a categoria nação:

[...] a diferença de grau de desenvolvimento entre o Nordeste e o Centro-Sul supera a que se observa entre esta última região e a média das naçôes industrializadas da Europa Ocidental [...] o problema do Nordeste, dentro da economia brasileira, apresenta maior gravidade que o do próprio Brasil, no conjunto das economias do mundo ocidental. ${ }^{63}$

As categorias região e nação perpassam todo o texto. Entretanto, elas não significam, necessariamente, a negação da existência das classes, nem mesmo a ausência delas na análise da problemática nordestina. ${ }^{64}$ Já se observou que o "risco à unidade nacional" seria, segundo os dois documentos em exame, provocado por conflitos de classes que oporiam regiōes contra regiōes. Tratar-se-ia de um conflito de classes estranho, que colocaria trabalhadores ao lado de patrões contra trabalhadores de outra região. Assim, o problema não é a ausência da classe, mas sua subordinação à regiãa.

Quando examina o nordeste isolado do restante do país, Furtado parece colocar a ênfase nas clivagens sociais, especialmente quando aborda o problema do semi-árido, observando que a estrutura social, e não exatamente a seca, constitui o maior problema da área. Um dos avanços do GTDN em relação às teses anteriores sobre o problema das secas no nordeste foi a explicação da natureza social e política, e não apenas climática do problema. Isso transparece na questão do semi-árido. Como observa Furtado:

[...] do ponto de vista do conjunto da economia nordestina a seca constitui uma crise de produção de magnitude limitada [...] não representou, em 1951, mais de 5 por cento. Mas convém frisar que os efeitos dessa crise se concentram em um grupo de população sem nenhum meio de defesa. ${ }^{65}$

Em outras palavras, os efeitos da seca não atingem a "região" e, sim, os trabalhadores ("um grupo da população").

Observado no seu conjunto, a interpretação de Furtado nos dois textos em análise mostra-se presa tanto aos conceitos de região como de nação. Esta, na realidade, seria, em última instância, a sua preocupação principal, sendo o nordeste apenas uma parte dela. Desenvolver o nordeste, para ele, equivaleria a eliminar os riscos à unidade nacional, portanto, à formação da nação. Para Furtado (e na SUDE$\mathrm{NE}$ original), a questão regional estava subordinada à sua visão e ao seu projeto de "nação". ${ }^{66}$

Há diversas críticas às proposições nacionalistas de Furtado, entre as quais se destacam a inviabilidade da "economia nacional" e a incapacidade do autor em perceber/considerar as transformações das economias brasileira e internacional na passagem dos anos 1950-1960.

Maria Odete Santos realiza uma interessante análise da "nação e da mundialização" no pensamento de Furtado. Para ela, a obra do autor sofre uma importante inflexão a partir de 1968, quando ele deixaria de acreditar na possibilidade de uma nação economicamente autônoma e começaria a perceber/discutir, de forma clara, as relações internacionais próprias da economia capitalista que, até então, ele ignorava ou deixava em segundo plano. ${ }^{67}$ De acordo com a autora, para Furtado, a formação/consolidação da nação é sinônimo de superação do subdesenvolvimento, algo que só se faria pela autonomização da economia. Nesse processo, o capital estrangeiro desempenharia um importante papel, só que seria controlado pelos “interesses nacionais". A avaliação de Santos é clara: tratava-se de uma utopia, a história o demonstrou. Aliás, segundo ela, foi o entendimento inadequado da história um dos fundamentos da utopia e uma das causas do seu fracasso. Isso se manifestaria nas leituras equivocadas de Furtado quanto aos processos de desenvolvimento e subdesenvolvimento que o autor via como fenômenos independentes entre si. Daí a crença de que seria possível a constituição de uma "economia nacional autônoma”, similarmente ao que teriam conseguido os países centrais desenvolvidos.

Embora bem urdida, a tese de Maria Odete Santos parece contradizer aspectos importantes de livros fundamentais de Furtado, como Formação Econômica do Brasil e Desenvolvimento e Subdesenvolvi- 
mento. Um dos fundamentos da tese de Santos é de que Furtado entende o "subdesenvolvimento" como "autônomo", sem relaçóes com o "desenvolvimento". Todavia, no conjunto da obra de Furtado, estão claros os vínculos entre os dois processos. De fato, ele não explora a fundo esse tema, mas isso é muito distante de ignorância ou desconsideração.

Mesmo na passagem em que Furtado fala expressamente em autonomia do subdesenvolvimento, o significado é distinto do que afirma Santos:

O subdesenvolvimento é, portanto, um processo histórico autônomo, e não uma etapa pela qual tenham, necessariamente, passado as economias que já alcançaram grau superior de desenvolvimento. Para captar a essência do problema das atuais economias subdesenvolvidas, necessário se torna levar em conta essa peculiaridade. ${ }^{68}$

O autor estava enfatizando as formas historicamente distintas como se processou o desenvolvimento capitalista no interior da Europa, em países como os EUA e Austrália e, por fim, em áreas como a América Latina. $\mathrm{O}$ intuito era salientar as especificidades históricas e combater as visóes padronizadoras, etapistas do processo. Assim, a autonomia é sinônimo de peculiaridade. Mesmo porque, logo na sequência do texto, o autor afirma que é a expansão das empresas estrangeiras nos países de economia "arcaica", précapitalista, que provoca a formação de estruturas duais, heterogêneas, logo, subdesenvolvidas. "O subdesenvolvimento, diz Furtado, não constitui uma etapa necessária do processo de formação das economias capitalistas modernas. É, em si, um processo particular, resultante da penetração de empresas capitalistas modernas em suas estruturas arcaicas." O significado de "autonomia" é o de que "[...] como fenômeno específico que é, o subdesenvolvimento requer um esforço de teorização autônomo.” ${ }^{69}$

Assim, pode-se afirmar que a teoria/projeto de nação/superação do subdesenvolvimento propugnada por Celso Furtado não ignorava o caráter internacional, mundial, da economia capitalista, nem as relações historicamente existentes entre o subdesenvolvimento e o desenvolvimento.

Mas nos projetos da CEPAL e de Furtado, o mercado jamais seria o único fator determinante do "desenvolvimento", pelo contrário, critérios políticos e sociais deveriam se sobrepor aos interesses econômicos stricto sensu, fossem eles nacionais ou internacionais.

A nação que Furtado projetava para o país teria autonomia econômica e política. Autonomia que não significa isolamento ou autarquia, pelo contrário, pressupunha uma grande interação com outras economias periféricas, bem como com os países centrais. O modelo com o qual se identificava Furtado era o Welfare State europeu. ${ }^{70}$ Era um projeto de nação capitalista, é óbvio.

Em verdade, a consecução do projeto cepalino, com o qual Furtado concordava, para a América Latina, implicava reformulaçoos nas relações comerciais internacionais. $\mathrm{Na}$ expressão de Reginaldo Moraes, a CEPAL sonhava e propunha um Estado do bem-estar mundial. ${ }^{71}$

$\mathrm{Na}$ nação que Furtado propõe, duas características fundamentais se destacam: o seu caráter democrático e, por causa desse caráter, a realização efetiva de políticas vigorosas de distribuição de renda. Esses dois elementos foram explicitados em dois livros escritos no calor dos debates do pré-64: Dialética do Desenvolvimento e A Pré-Revolução Brasileira. Coerente com o que propunha a CEPAL ${ }^{72}$, Furtado coloca a "manutenção" da democracia como uma condição para o "desenvolvimento social":

A consecução ou manutenção de um regime democrático aberto, em que as classes assalariadas podem organizar-se para lutar por objetivos próprios, deve ser considerada como condição necessária do desenvolvimento social em um país subdesenvolvido. É a partir desse ponto que se pode pensar em ação política para o desenvolvimento. ${ }^{73}$

Além de a democracia ser um valor fundamental, está claro o papel ativo a ser desempenhado pelas classes sociais, eliminando-se, pois, qualquer traço de paternalismo e/ou autoritarismo no projeto do autor. As classes sociais sempre existirão, diz Furtado. Mas os antagonismos inerentes à sociedade capitalista não eliminariam pontos em comum entre elas. $\mathrm{O}$ autor tenta, então, fazer uma conciliação entre as categorias "classe" e "nação": 
[...] a ambivalência ideológica fundamental está sempre presente, como reflexo do antagonismo de classes. Eliminá-la seria retirar à sociedade capitalista um dos fatores essenciais ao seu dinamismo. Como o desenvolvimento moderno se realizou no marco do Estado-Nação, através da formação e defesa dos mercados nacionais, os interesses do desenvolvimento encontraram sua expressão política máxima no nacionalismo, única ideologia capaz de integrar em sua plenitude interesses antagônicos de classe. ${ }^{74}$

Nesse trecho, aparece claramente o pragmatismo de Furtado quanto à ideia de nação, bem como seu equívoco quanto ao entendimento da dinâmica das classes. A primeira coisa que o trecho afirma é o efeito positivo da luta de classes para o desenvolvimento capitalista. É o que ele chama de a dialética do desenvolvimento. O segundo aspecto é que o autor enxerga a nação e o nacionalismo como instrumentos necessários a serem utilizados para se conseguir realizar propósitos maiores, a saber, a consecução do desenvolvimento social. O esforço de conciliar nação e classe se revelaria em vão: para além do território brasileiro, a burguesia nacional, progressivamente, aliava-se ao capital externo. Acima da nação, estava a classe que, por definição, é internacional.

Celso Furtado era economista por formação. Grande parte dos seus escritos privilegia os aspectos econômicos. Entretanto, o seu entendimento acerca do subdesenvolvimento e do desenvolvimento inclui incisivamente outros fatores que ele chama de "históricos", "culturais", "políticos". Assim, sua proposta de conciliar nação e classe e de orientar a relação da nação com o "mundo" é fundamentalmente política. Estabelecida a democracia como um valor indispensável, definida a nação como instrumento, o autor não hesita em identificar, no plano político, a superação do subdesenvolvimento:

O maior obstáculo a uma transição gradual está em que a reforma mais urgentemente necessitada [...] resulta ser a de mais difícil realização: a reforma política, visando [...] aumentar a representatividade dos órgãos que atuam em nome do povo. ${ }^{75}$

Realizada essa reforma, a consecução das outras, a agrária, por exemplo, seria viável dentro do marco institucional democrático.

A intransigente defesa da democracia como condição para qualquer opção política, era algo raro nos anos 1960 no Brasil. Como salienta Argelina Figueiredo ${ }^{76}$, tanto a "Direita" quanto a "Esquerda" viam a democracia como um meio para se realizar os seus fins. Nesse sentido específico, Celso Furtado, apesar de sua grande influência no período, representava um pensamento minoritário.

Talvez a melhor interpretação do projeto de Furtado esteja na afirmação recente de Francisco de Oliveira quanto ao significado da "nação" do autor: "[...] o espaço nacional é ainda a forma onde se pode construir um processo democrático, colocando a possibilidade concreta da intervenção do povo e das classes sociais dominadas [...] a concepção de Furtado não é nacionalista, nem populista: trata-se de uma concepção democrática." " Em outros termos, a constituição/preservação da "nação" é importante na medida em que permite a ação política, deixando em aberto, portanto, a possibilidade de influir sobre a economia, sobre o mercado.

\section{Gramsci e Furtado, Gramsci versus Furtado}

Em diversos aspectos, Gramsci e Furtado se assemelham. Ao se examinar dados básicos da biografia de ambos, nota-se que a história pessoal deles, especialmente a sua região de origem e os problemas que elas apresentavam, estão presentes ao longo de suas formulações teóricas e ações políticas. O foco colocado no regional em nada parece incompatível com o fato de que os dois se tornaram pensadores conhecidos e influentes no âmbito internacional.

Homens de ação, intelectuais engajados, Gramsci e Furtado participaram, cada um em seu tempo e em seu país, ativamente das lutas sociais e políticas. Aliaram a teoria à prática, algo difícil em se tratando de ciências sociais e humanas. Para nenhum dos dois a reflexão e refinamento teórico tinham sentido se não pudessem contribuir, ou mesmo materializar-se de forma direta, em propostas concretas para 
a sociedade. Nesse sentido, suas formulações tornaram-se linhas mestras da ação política dos próprios autores, bem como de segmentos sociais por eles influenciados. É ainda notável como ambos conseguiram manter uma razoável coerência entre o escrito/teorizado e o executado (ou pelo menos projetado e intentado, como foi o caso da SUDENE original).

Seus estudos eram radicalmente embasados na história. Gramsci investiga as origens da questão meridional no processo de unificação italiana cuja forma ele denominou de a revolução passiva. Furtado retroage ao período colonial para encontrar as raízes do problema nordestino. Nas palavras do primeiro, “[...] se escrever história significa fazer história do presente, é grande livro de história aquele que, no presente, ajuda as forças em desenvolvimento a se tornarem mais conscientes de si mesmas e, portanto, mais concretamente ativas e operosas." 78 Já Furtado afirma em sua autobiografia que "[...] considerava a economia como um instrumento para penetrar no social e no político e avançar na compreensão da História, particularmente quando esta ainda se exibia como presente em nossos olhos." ${ }^{\prime 9}$

Gramsci e Furtado também se igualam na capacidade que tiveram, em virtude do seu prestígio como pensadores, de colocar a questão regional como um problema nacional. Para ambos, o entendimento e solução do problema tinham implicações nacionais. Podem-se encontrar trações regionalistas no Gramsci da juventude e em trechos dos livros de Furtado. Todavia, no conjunto do pensamento dos autores, a questão regional é, na realidade, uma peça no quebra-cabeça de âmbito nacional. Gramsci recomenda uma aliança de classe entre operários do norte e camponeses do sul contra os latifundiários do sul e empresários do norte. A escala dessa luta é nacional. O problema do Mezzogiorno se explica por suas relaçóes com o restante do país; sua solução também exigia a reformulação da ordem social em toda a Itália.

Furtado investe suas energias no projeto SUDENE, mas as razões profundas do problema nordeste por ele identificadas, bem como o equacionamento que propõe, exigia reformulações de âmbito nacional. Acima da região estava a nação. Sem um projeto efetivo para esta, o enfrentamento da questão nordeste era impossível. A inevitável relação entre a escala regional e nacional ficou evidente em 1964 quando o golpe civil-militar desfez a fantasia de Furtado.

Além da ênfase na escala nacional, pode-se dizer que tanto as propostas de Gramsci quanto as de Furtado tinham, no limite, alcance internacional. A revolução socialista postulada pelo primeiro nunca foi um projeto nacionalista. Ela poderia até tomar a forma nacionalista e se restringir à Itália temporariamente, mas seu caráter era de classe e, nessa perspectiva, internacional. A construção da nação sonhada pelo segundo não seria possível sem se proceder a reformulações nas relações entre centro e periferia. Furtado, assim como Raul Prebisch ${ }^{80}$, tinha clara percepção de que o desenvolvimento efetivo do Brasil e da América Latina exigiria transformações no sistema capitalista em escala maior, algo que só seria possível com um novo concerto entre as nações.

Os projetos de revolução (Gramsci) e nação (Furtado) dos dois pensadores fracassaram. Ambos permaneceram apenas como projetos. O primeiro foi vencido pelo fascismo de Mussolini e o segundo pela modernização conservadora conduzida pelo regime civil-militar no Brasil.

Apesar de diversos elementos convergentes, os dois autores em análise divergem em vários aspectos. Entre estes, destacam-se o reformismo de Furtado, a opção revolucionária (socialista) de Gramsci e as concepções que apresentam acerca do Estado e dos intelectuais.

Gramsci, mesmo ampliando e enriquecendo o conceito de Estado (sociedade civil + sociedade política), pensa o Estado de forma indissociada da estrutura e conflito de classes e postula a sua superação, tanto das classes quanto do Estado, pela via revolucionária. ${ }^{81}$ Já Furtado, embora reconheça a existência e papel ativo das classes no processo histórico, não postula a extinção do Estado, mas sim o seu constante ajuste às demandas impostas pela sociedade de classe. Ajustes que seriam a um só tempo consequência da luta de classe e mecanismo de contenção desta nos marcos institucionais democráticos. ${ }^{82}$

Em texto de 1962, dedicado à análise da "pré-revolução" e das alternativas que se colocavam para o desenvolvimento do país, Furtado aproxima-se de Gramsci, mas, possivelmente por não conhecer o pensador italiano, faz uma leitura estreita do marxismo. 
Inicialmente Furtado "identifica" o marxismo-leninismo: "O marxismo-leninismo [...] postula a inevitabilidade da revolução violenta, liderada por um partido de profissionais [...] devendo a nova ordem ser assegurada por um governo ditatorial." Em seguida, identifica as sociedades em que esse "modelo" foi bem-sucedido: "[...] essa técnica foi forjada e aperfeiçoada na luta pela destruição de uma estrutura político-social totalmente rígida, que era o tsarismo." ${ }^{83}$ Gramsci diz praticamente a mesma coisa quando observa que nas sociedades orientais, onde a sociedade civil era pouco desenvolvida, o Estado limitava-se praticamente à estrutura repressora e, por isso, a revolução era igual à tomada do aparelho de Estado.

Outra era a situação nas "sociedades abertas", diz Furtado: "O exemplo da Europa Ocidental parece ser conclusivo: grandes máquinas partidárias de orientação marxista-leninista ficaram traumatizadas diante da realidade político-social em permanente mutação." Nestas, continua o autor, “[...] o Estado deixa de ser simples ditadura de classe, para transformar-se num sistema compósito, representativo de várias classes, se bem que sob a égide de uma." ${ }^{84}$ Gramsci concordaria com Furtado: nas sociedades ocidentais a revolução teria de ser conquistada passo a passo, como numa guerra de posiçôes. Nestas sociedades, o Estado é ampliado: além da repressão, inclui uma ampla rede de organizações da sociedade civil dirigida pela burguesia hegemônica. ${ }^{85}$

Furtado faz uma leitura similar à que Gramsci fizera cerca de três décadas atrás. Todavia, os dois autores tiram conclusões distintas do mesmo diagnóstico. O primeiro conclui que a revolução "marxistaleninista" é inviável; o segundo repensa a forma da revolução. O Brasil, observa Furtado, apesar de ainda distante dos países europeus ocidentais, já era uma sociedade razoavelmente aberta, conquista que não deveria ser colocada em risco com o uso da fórmula marxista-leninista de transformação social, cujo resultado, seguramente, seria a constituição de modelos fechados como o soviético. Na base do argumento de Furtado há duas premissas: a) o regime de Stálin é o resultado da materialização do projeto marxista: progresso econômico ao custo da liberdade e b) o marxismo era incapaz de dar respostas democráticas à problemática social das sociedades ocidentais complexas. São duas simplificações. A primeira parece comum a um texto engajado, produto e parte constituinte de um tempo de forte agitação política como o Brasil no pré-64. ${ }^{86} \mathrm{~A}$ segunda seria facilmente evitada com uma leitura dos escritos do pensador italiano. Parece que Furtado nunca esteve tão perto de Gramsci quanto no exame dessa questão e ao mesmo tempo bem distante quanto às conclusões que dela extrai.

Qual deveria ser, no interior desse processo histórico, o papel dos intelectuais? Os dois autores identificam-se como intelectuais, mas divergem quanto ao significado disso. Gramsci é categórico ao afirmar que os intelectuais não formam uma classe à parte e que, mesmo tendo uma independência relativa, compõem as classes fundamentais, sendo indispensáveis à sua organização e expressão. ${ }^{87}$

No exame da mesma questão, Furtado compartilha da visão de Karl Mannheim para quem,

[...] na sociedade de massa, dividida em classes, os intelectuais constituem não uma classe no sentido próprio da palavra mas uma camada em si mesma, na medida em que é formada por um conjunto de indivíduos provenientes das classes mais diversas, não ligado a nenhuma classe em particular, socialmente independente, pairando acima das classes contrapostas. ${ }^{88}$

Celso Furtado foi muito influenciado por essa ideia, como ele mesmo explica:

Seguindo Mannheim, eu tinha uma certa ideia do papel da intelligentsia [...]. Sentia-me acima dos condicionantes criados por minha inserção social e estava convencido de que o desafio consistia em instilar um propósito social no uso dessa liberdade. ${ }^{89}$

Coerentes com suas concepções, Gramsci trabalhava pela revolução na Itália, operando como um intelectual da classe operária ou da aliança operário-camponesa; Furtado acreditava firmemente na sua ação racional e "independente" e na intervenção do Estado no enfrentamento da questão nordestina e formação da nação brasileira.

Os projetos de Furtado e Gramsci não lograram êxito. As questões nordeste e meridional transformaram-se profundamente nas últimas décadas. Talvez, um dos maiores legados dos dois pensadores pa- 
ra o mundo de hoje, no qual os intelectuais cada vez mais mergulham em um ceticismo passivo e na mera contemplação ${ }^{90}$, seja a necessária integração teoria-prática e a certeza de que a primeira sem a segunda é inútil, ideias centrais na biografia e pensamento dos dois autores aqui estudados.

\section{Notas}

${ }^{1}$ A publicação completa mais recente, no Brasil, dos cadernos da prisão de Gramsci é de 2004: GRAMSCI, Antonio. Cadernos do Cárcere. Edição e tradução de Carlos Nelson Coutinho; co-edição de Luiz Sérgio Henriques e Marco Aurélio Nogueira. 6 v., $3^{a}$ ed. Rio de Janeiro: Civilização Brasileira, 2004.

${ }^{2}$ COUTINHO, Carlos Nelson. Gramsci. Um estudo sobre o seu pensamento político. Rio de Janeiro: Campus, 1989, p. 77. Segundo Coutinho, a libertação de Gramsci foi uma manobra de Mussolini, para evitar que ele morresse como prisioneiro do fascismo, haja vista o fato de sua saúde já estar bastante debilitada quando de sua libertação.

${ }^{3}$ FURTADO, Celso. Celso Furtado: obra autobiográfica. Rio de Janeiro: Paz e Terra, 1997, 3 v., v. 1, pp. 9-14.

${ }^{4}$ FURTADO, Celso. A operação Nordeste. Rio de Janeiro: ISEB, 1959, e GTDN. Uma política de desenvolvimento econômico para o Nordeste. In: TAMER, Alberto. O mesmo Nordeste. São Paulo: Herder, 1968, pp. 173-232.

5 "Furtado explicou nosso atraso, diz economista". Folha de São Paulo. São Paulo, 28 nov. 2004, p. A 10.

GRAMSCI, Antonio. A questão meridional. Rio de Janeiro: Paz e Terra, 1987.

${ }^{6}$ GRAMSCI, Antonio. A questão meridional, op. cit.

${ }^{7}$ GRAMSCI, Antonio. A questão meridional, op. cit., p. 164. Nesse trecho, Gramsci se refere aos velhos intelectuais do sul da Itália.

${ }^{8}$ Autores como Carlos Nelson Coutinho e Hugues Portelli rejeitam veementemente interpretações que afirmam ter Gramsci saído dos marcos do marxismo, ou então, como quer Norberto Bobbio, ter colocado a primazia na superestrutura. Ver: COUTINHO, Carlos Nelson. Gramsci: um estudo sobre o seu pensamento político, op. cit. e PORTELLI, Hugues. Gramsci e o bloco histórico. Rio de Janeiro: Paz e Terra, 1977.

${ }^{9}$ COUTINHO, Carlos Nelson, op. cit., pp. 8-9.

${ }^{10}$ MACCIOCCHI, Maria-Antonietta. A favor de Gramsci. 2 ed. Rio de Janeiro: Paz e Terra, 1977, p. 103.

${ }^{11}$ Gramsci dedicou muito de suas reflexões ao Risorgimento. Cf. GRAMSCI, Antonio. Cadernos do Cárcere. Edição e tradução de Carlos Nelson Coutinho; co-edição de Luiz Sérgio Henriques e Marco Aurélio Nogueira. 3 ed. Rio de Janeiro: Civilização Brasileira, 2004, v. 5, pp. 13-128, ver especialmente pp. 62-65; MACCIOCCHI, Maria-Antonietta, op. cit., p. 114; COUTINHO, Carlos Nelson, op. cit., pp. 67-74.

${ }^{12}$ GRAMSCI, Antonio. A questão meridional, op. cit., p. 154.

${ }^{13}$ MACCIOCCHI, Maria-Antonietta, op. cit., pp. 113-114.

${ }^{14}$ As expressōes "Campo Político" e "Campo Ideológico" são do próprio Gramsci. Entendemos que, a julgar pelo sentido em que elas estão utilizadas, poderiam ser substituídas pelos conceitos de "Sociedade Política” e "Sociedade Civil”, categorias que Gramsci desenvolveria, posteriormente, na prisão. Cf. GRAMSCI, Antonio. Maquiavel, a politica e o Estado Moderno. 2 ed. Rio de Janeiro: Civilização Brasileira, 1976.

${ }^{15}$ PORTELLI, Hugues, op. cit., pp. 157-158.

${ }^{16}$ Esses conceitos seriam aprofundados nos Cadernos, já na prisão. Em A Questão Meridional, os dois tipos de intelectuais são colocados com outros nomes. Cf. GRAMSCI, Antonio. Cadernos do Cárcere. Edição e tradução de Carlos Nelson Coutinho; co-edição de Luiz Sérgio Henriques e Marco Aurélio Nogueira. 3 ed. Rio de Janeiro: Civilização Brasileira, 2004, v. 1, pp. 93126 e GRAMSCI, Antonio. Os intelectuais e a organização da cultura. 7 ed. Rio de Janeiro: Civilização Brasileira, 1989.

${ }^{17}$ GRAMSCI, Antonio. A questão meridional, op. cit., p. 155.

${ }^{18}$ GRAMSCI, Antonio. A questão meridional, op. cit., p. 155.

${ }^{19}$ MACCIOCCHI, Maria-Antonietta. A favor de Gramsci, op. cit., p. 113.

${ }^{20}$ PORTELLI, Hugues. Gramsci e o bloco histórico, op. cit., p. 122.

${ }^{21}$ GRAMSCI, Antonio. A questäo meridional, op. cit., pp. 161-162.

${ }^{22}$ GRAMSCI, Antonio. A questão meridional, op. cit., p. 77.

${ }^{23}$ GRAMSCI, Antonio. A questão meridional, op. cit., p. 139.

${ }^{24}$ COUTINHO, Carlos Nelson, op. cit., p. 69.

${ }^{25}$ GRAMSCI, Antonio. A questão meridional, op. cit., pp. 139-140.

${ }^{26}$ GRAMSCI, Antonio. A questão meridional, op. cit., p.146.

${ }^{27}$ MACCIOCCHI, Maria-Antonietta. A favor de Gramsci, op. cit., p. 134. 
${ }^{28}$ GRAMSCI, Antonio. A questão meridional, op. cit., p. 164.

${ }^{29}$ SECCO, Lincoln. Gramsci e o Brasil. São Paulo: Cortez, 2002.

${ }^{30}$ MACCIOCCHI, Maria-Antonietta. A favor de Gramsci, op. cit., p. 102.

${ }^{31}$ MACCIOCCHI, Maria-Antonietta. A favor de Gramsci, op. cit., p. 102.

32 Cf. SECCO, Lincoln. Gramsci e o Brasil, op. cit. e COUTINHO, Carlos Nelson, op. cit.

${ }^{33}$ SILVEIRA, Rosa Maria Godoy. O regionalismo nordestino: existência e consciência da desigualdade regional. São Paulo: Moderna, 1984 e CASTRO, Iná Elias. O mito da necessidade: discurso e prática do regionalismo nordestino. Rio de Janeiro: Bertrand Brasil, 1992.

${ }^{34}$ Cf. FURTADO, Celso. Formação econômica do Brasil. São Paulo: Publifolha, 2000, FURTADO, Celso. Dialética do desenvolvimento. 2 ed. Rio de Janeiro: Fundo de Cultura, 1964 (especialmente a parte 3: "O processo revolucionário no nordeste”, pp. 143-181) e FURTADO, Celso. A pré-revolução brasileira. Rio de Janeiro: Fundo de Cultura, 1962 (especialmente a parte 3: "O problema do nordeste", pp. 47-63).

${ }^{35}$ GTDN, op. cit. O GTDN - Grupo de Trabalho de Desenvolvimento do Nordeste foi criado no Governo JK para estudar os problemas do Nordeste. O documento Uma política, embora não assinado, é de autoria de Celso Furtado, coordenador do GTDN.

${ }^{36}$ Para um aprofundamento da idéia de nação e sua importância no pensamento de Furtado cf. KALVAN, Fábio Ricardo. O lugar da nação: estudo da abordagem da nação no Dual-estruturalismo de Celso Furtado e nos estudos sobre a dependência de Fernando Henrique Cardoso. Dissertação de Mestrado apresentada ao Programa de Pós-Graduação em Sociologia da USP. São Paulo, 2000. e SANTOS, Maria Odete. Nação e mundialização no pensamento de Celso Furtado. Tese de Doutorado apresentada ao Programa de Pós-Graduação em História da Unicamp. Campinas, 1998.

${ }^{37}$ GTDN, op. cit., p. 174.

${ }^{38}$ GTDN, op. cit., p. 186.

${ }^{39}$ GTDN, op. cit., p. 187. Essa tese de uma aliança operários-burgueses contra operários foi duramente criticada por OLIVEIRA, Francisco de. Elegia para uma re(li)gião: Sudene, Nordeste, planejamento e conflito de classes. 6 ed. Rio de Janeiro: Paz e Terra, 1993. Outro ponto criticado por Oliveira é o de Furtado não considerar o importante fato de que, ao empresariado do centro-sul, a abundância de mão-de-obra é benéfica, ao rebaixar os salários, portanto, diminuir os custos. Por que a burguesia se oporia à existência desse reservatório de mão-de-obra?

${ }^{40}$ FURTADO, Celso. A operação Nordeste, op. cit., p. 16. O livro A operação Nordeste é uma reprodução de uma palestra proferida por Furtado, para oficiais das Forças Armadas, no dia 13 de junho de 1959, no Instituto Superior de Estudos Brasileiros - ISEB.

${ }^{41}$ Cf. COHN, Amélia. Crise regional e planejamento (o processo de criação da SUDENE). São Paulo: Perspectiva, 1976 e HIRSCHAMN, Albert. Política econômica na América Latina. São Paulo: Fundo de Cultura, 1965.

${ }^{42}$ Esse tratamento dado à questão nordestina é uma transposição das análises cepalinas (pensadas para países). Segundo Wilson Cano, foi esse um dos principais equívocos da SUDENE. CANO, Wilson. Celso Furtado e a questão regional no Brasil. In: TAVARES, Maria da Conceição (Org.). Celso Furtado e o Brasil. São Paulo: Perseu Abramo, 2000, pp. 93-120 e CANO, Wilson. Desequilíbrios regionais no Brasil: alguns pontos controversos. In: MARANHĀO, Silvio (Org.). A questão Nordeste. Rio de Janeiro: Paz e Terra, 1984, pp. 55-70.

${ }^{43}$ GTDN, op. cit., p. 174.

${ }^{44}$ GTDN, op. cit., p. 190.

${ }^{45}$ É interessante notar como a categoria "Nordeste", assim como "Centro-Sul”, aparecem como "entidades" gerais, e não aparecem, pelo menos neste trecho, os empresários do Sul ou do Nordeste.

${ }^{46}$ FURTADO, Celso. A operação Nordeste, op. cit., pp. 42-43.

${ }^{47}$ FURTADO, Celso. A operação Nordeste, op. cit., p. 43.

${ }^{48}$ PREBISCH, Raúl (1949). O desenvolvimento econômico da América Latina e alguns de seus problemas principais. In: BIELSCHOWSKY, Ricardo (Org.). Cinqüenta anos de pensamento na CEPAL. Rio de Janeiro: Record, 2000, 2 v., pp. 69-136.

${ }^{49}$ Uma crítica a essas teses do GTDN pode ser vista em CANO, Wilson. Desequilíbrios regionais no Brasil: alguns pontos controversos. In: MARANHĀO, Sílvio (Org.). A questão Nordeste, op. cit., pp. 55-70.

${ }^{50}$ Não há, nos textos em análise, qualquer ideia de obstacularização ao desenvolvimento do capitalismo no Brasil. Há, sim, a tese de que a escassez de alimentos, devido à estrutura agrária arcaica, impedia a industrialização no nordeste (vale registrar que, mesmo a tese da insuficiência de alimentos, emperrando a industrialização atual (até 1959) no nordeste, deve ser vista com cuidado. Na página 228, o GTDN é claro quanto a esse aspecto. No entanto, não se deve simplificar tanto o problema, uma vez que, em outras passagens do mesmo texto e em $A$ Operação Nordeste, o autor diz claramente que a industrialização e o aumento da oferta de alimentos teriam que caminhar concomitantemente, não sendo, por exemplo, viável aumentar a produção de alimentos sem o aumento da industrialização, já que não haveria mercado consumidor para tais alimentos). 
Assim, a crítica de Amélia Cohn (op. cit.), segundo a qual o GTDN apontava a economia do nordeste como entrave ao desenvolvimento do país, parece improcedente. O que o GTDN afirmava é que as disparidades regionais levariam a uma concorrência e conflito entre os próprios trabalhadores o que, aliás, teria como consequência não a paralisia do centro-sul, mas a formação de uma aliança operários-patrões de uma região contra a outra e, por conseguinte, o risco à unidade nacional. O que parece ter ocorrido foi uma "contaminação" dos textos de 1959 (Uma Política e A Operação Nordeste) pelos escritos de Furtado nos anos 60, quando a tese estagnacionista foi defendida (FURTADO, Celso. Subdesenvolvimento e estagnação na América Latina. Rio de Janeiro: Civilização Brasileira, 1966).

${ }^{51}$ GTDN, op. cit., p. 179.

52 Essa crítica é muito divulgada. Cf., por exemplo, SOUZA, João Gonçalves de. O Nordeste brasileiro: uma experiência de desenvolvimento regional. Fortaleza: BNB, 1979.

${ }^{53}$ GTDN, op. cit., p. 231.

${ }^{54}$ GTDN, op. cit., p. 177.

${ }^{55}$ A esse respeito, cf. OLIVEIRA, Francisco. Elegia para uma re(li)giāo, op. cit.; SOUZA, João Gonçalves de, op. cit.; CARVALHO, Inaiá Maria Moreira de; HAGUETTE, Teresa Maria F. (Orgs.). Trabalho e condiçôes de vida no Nordeste brasileiro. São Paulo: HUCITEC/Brasília: CNPq, 1984; e HOLANDA, Nilson. Incentivos fiscais e desenvolvimento regional. Fortaleza: Banco do Nordeste do Brasil, 1975.

${ }^{56}$ Acerca da intenção de Furtado de manter a economia nordestina sob o controle da burguesia regional, ver ARAÚJO, Tânia Bacelar de. A "questão regional" e a "questão nordestina". In: TAVARES, Maria da Conceição (Org.). Celso Furtado e o Brasil, op. cit., p. 78.

${ }^{57}$ Ver especialmente COHN, Amélia. op. cit. e ROBOCK, Stefan H. Desenvolvimento econômico regional: o nordeste brasileiro. Rio de Janeiro: Fundo de Cultura, 1964; OLIVEIRA, Francisco de. Elegia para uma re(li)giāo: Sudene, Nordeste, planejamento e conflito de classes. 6 ed. Rio de Janeiro: Paz e Terra, 1993; ARAÚJO, Tânia Bacelar de. Industrialização do Nordeste: intenções e resultados. In: MARANHÃO, Sílvio (Org.). A questão Nordeste, op. cit.; e CARVALHO, Inaiá Maria Moreira de. O Nordeste e o regime autoritário: discurso e prática do planejamento regional. São Paulo: Hucitec, 1982.

${ }^{58}$ MARANHÃO, Silvio. Estado e planejamento regional: A experiência do Nordeste brasileiro. In: A questão Nordeste, op. cit., p. 92.

${ }^{59}$ Uma questão interessante é saber até que ponto o regionalismo era compartilhado pelos chamados movimentos populares. Para Gadiel Perruci, essa "ideologia” era das elites e de "intelectuais de classe média”, não dos movimentos populares. Cf. PERRUCI, Gadiel. A formação histórica do Nordeste e a questão regional. MARANHĀO, Sílvio (Org.). A questão nordeste, op. cit.

${ }^{60}$ FURTADO, Celso. A operação Nordeste, op. cit., pp. 33 e 68.

${ }^{61}$ OLIVEIRA, Francisco de. A economia brasileira: crítica à razão dualista. 4 ed. Petrópolis: Vozes, 1981, p. 13.

${ }^{62}$ PERRUCI, Gadiel. A formação histórica do Nordeste e a questão regional. MARANHÃO, Sílvio (Org.). A questão nordeste, op. cit.

${ }^{63}$ GTDN, op. cit. pp. 180-181.

${ }^{64} \mathrm{O}$ papel das classes sociais no pensamento de Furtado está mais bem expresso em FURTADO, Celso. A pré-revolução brasileira. Rio de Janeiro: Fundo de Cultura, 1962 e FURTADO, Celso. Dialética do desenvolvimento. 2 ed. Rio de Janeiro: Fundo de Cultura, 1964. Em Dialética do desenvolvimento, o autor dedica um capítulo especial ao Nordeste, "O Processo Revolucionário no Nordeste", no qual identifica e reconhece, com muito mais desenvoltura do que no texto do GTDN, os conflitos de classes existentes no interior da região.

${ }^{65}$ GTDN, op. cit., p. 205.

${ }^{66}$ No pensamento de Furtado, resume Maria Odete Santos, "O desenvolvimento econômico nacional não se deve subordinar ao desenvolvimento regional.” SANTOS, Maria Odete, op. cit., p. 119.

${ }^{67}$ SANTOS, Maria Odete, op. cit.

${ }^{68}$ FURTADO, Celso. Desenvolvimento e subdesenvolvimento. Rio de Janeiro: Fundo de Cultura, 1961, pp. 173-174.

${ }^{69}$ FURTADO, Celso. Desenvolvimento e subdesenvolvimento, op. cit., pp. 184-185.

${ }^{70}$ CEPÊDA, Vera Alves. Raizes do pensamento político de Celso Furtado: desenvolvimento, nacionalidade e Estado democrático. Dissertação de Mestrado apresentada ao Programa de Pós-Graduação em Ciências Sociais e Política da USP. São Paulo, 1998.

${ }^{71}$ MORAES, Reginaldo C. Correa. Planejamento: ditadura ou democracia? Tese de Doutorado apresentada ao Programa de Pós-Graduação em Filosofia da USP. São Paulo, 1987.

${ }^{72}$ A defesa de uma distribuição de renda aparece em praticamente todos os textos da CEPAL, com especial nitidez em PREBISCH, Raúl. Dinâmica do desenvolvimento latino-americano. Rio de Janeiro: Fundo de Cultura, 1964.

${ }^{73}$ FURTADO, Celso. Dialética do desenvolvimento, op. cit., p. 88.

${ }^{74}$ FURTADO, Celso. Dialética do desenvolvimento, op. cit., p. 69. 
${ }^{75}$ FURTADO, Celso. Dialética do desenvolvimento, op. cit., pp. 110-111.

${ }^{76}$ FIGUEIREDO, Argelina Cheibub. Democracia ou reformas? Alternativas democráticas à crise política: 1961-1964. São Paulo: Paz e Terra, 1993.

77 OLIVEIRA, Francisco de. Um republicano exemplar. In: BRESSER-PEREIRA, Luiz Carlos; REGO, José Marcio (Orgs.). A grande esperança em Celso Furtado. São Paulo: Editora 34, 2001, p. 219.

${ }^{78}$ GRAMSCI, Antonio. Cadernos do Cárcere, op. cit., v. 5, p. 37.

${ }^{79}$ FURTADO, Celso. A fantasia organizada. In: Celso Furtado: obra autobiográfica. Rio de Janeiro: Paz e Terra, 1997, 3 v., v. I, p. 98.

${ }^{80}$ Acerca disso cf. especialmente MORAES, Reginaldo C. Correa, op. cit.

${ }^{81}$ GRAMSCI, Antonio. Maquiavel, a política e o Estado Moderno, op. cit. Sobre "a sociedade regulada e o fim do Estado" em Gramsci cf. COUTINHO, Carlos Nelson, op. cit., pp. 135-143.

${ }^{82} \mathrm{O}$ argumento de Furtado está bem expresso em FURTADO, Celso. Dialética do desenvolvimento, op. cit., especialmente na primeira parte intitulada "Dialética do desenvolvimento", pp. 11-90.

${ }^{83}$ FURTADO, Celso. A pré-revolução brasileira, op. cit., p. 25.

${ }^{84}$ FURTADO, Celso. A pré-revolução brasileira, op. cit., p. 25.

${ }^{85}$ GRAMSCI, Antonio. Maquiavel, a política e o Estado Moderno, op. cit.

${ }^{86}$ Cf. OLIVEIRA, Francisco. A navegação venturosa. In: OLIVEIRA, Francisco (Org.). Celso Furtado. São Paulo: Ática, 1983, pp. 17-18 (Grandes Cientistas Sociais, 33).

${ }^{87}$ GRAMSCI, Antonio. Cadernos do Cárcere, op. cit., v. 5, pp. 64-65, 93.

${ }^{88}$ BOBBIO, Norberto. Os intelectuais e o poder. São Paulo: Unesp, 1997, p. 130.

${ }^{89}$ FURTADO, Celso. A fantasia organizada, op. cit., v. I, p. 101. Sobre a influência de Mannheim em Furtado, ver também DANTAS, José Adalberto Mourão. A problemática desenvolvimento-subdesenvolvimento no pensamento de Celso Furtado: os fundamentos de um pensamento original. Tese de Doutorado apresentada ao Programa de Pós-Graduação em História Econômica da USP. São Paulo, 1999, especialmente o capítulo IV: "A razão planejada".

${ }^{90}$ RIDENTI, Marcelo. Cultura e política: os anos 1960-1970 e sua herança. In: DELGADO, Lucília de Almeida Neves; FERREIRA, Jorge (Orgs.). O Brasil Republicano: o tempo da ditadura. Rio de Janeiro: Civilização Brasileira, 2003, pp. 133-166, $160-164$.

\section{Referências bibliográficas}

ARAÚJO, Tânia Bacelar de. Industrialização do Nordeste: intençōes e resultados. In: MARANHĀO, Sílvio (Org.). A questão Nordeste. Rio de Janeiro: Paz e Terra, 1984.

. A 'questão regional' e a 'questão nordestina'. In: TAVARES, Maria da Conceição (Org.). Celso Furtado e o Brasil. Rio de Janeiro: Paz e Terra, 1984, pp. 55-70.

BOBBIO, Norberto. Os intelectuais e o poder. São Paulo: Unesp, 1997.

CANO, Wilson. Celso Furtado e a questão regional no Brasil. In: TAVARES, Maria da Conceição (Org.). Celso Furtado e o Brasil. São Paulo: Perseu Abramo, 2000, pp. 93-120.

. Desequilíbrios regionais no Brasil: alguns pontos controversos. In: MARANHÃO, Silvio (Org.). A questão Nordeste. Rio de Janeiro: Paz e Terra, 1984, pp. 55-70.

CARVALHO, Inaiá Maria Moreira de. O Nordeste e o regime autoritário: discurso e prática do planejamento regional. São Paulo: Hucitec, 1982.

; HAGUETTE, Teresa Maria F. (Orgs.). Trabalho e condiçôes de vida no Nordeste brasileiro. São Paulo: Hucitec / Brasília: CNPq, 1984.

CASTRO, Iná Elias. O mito da necessidade: discurso e prática do regionalismo nordestino. Rio de Janeiro: Bertrand Brasil, 1992.

CEPÊDA, Vera Alves. Raizes do pensamento politico de Celso Furtado: desenvolvimento, nacionalidade e Estado democrático. Dissertação de Mestrado apresentada ao Programa de Pós-Graduação em Ciências Sociais e Política da USP. São Paulo, 1998.

COHN, Amélia. Crise regional e planejamento (o processo de criação da SUDENE). São Paulo: Perspectiva, 1976.

COUTINHO, Carlos Nelson. Gramsci. Um estudo sobre o seu pensamento político. Rio de Janeiro: Campus, 1989. 
DANTAS, José Adalberto Mourão. A problemática desenvolvimento-subdesenvolvimento no pensamento de Celso Furtado: os fundamentos de um pensamento original (?). Tese de Doutorado apresentada ao Programa de Pós-Graduação em História Econômica da USP. São Paulo, 1999.

FIGUEIREDO, Argelina Cheibub. Democracia ou reformas? Alternativas democráticas à crise política: 1961-1964. São Paulo: Paz e Terra, 1993.

FURTADO, Celso. Celso Furtado: obra autobiográfica. Rio de Janeiro: Paz e Terra, 1997, 3ํv. . Desenvolvimento e subdesenvolvimento. Rio de Janeiro: Fundo de Cultura, 1961.

. Dialética do desenvolvimento. 2 ed. Rio de Janeiro: Fundo de Cultura, 1964.

. Formação econômica do Brasil. São Paulo: Publifolha, 2000.

. A operação Nordeste. Rio de Janeiro: ISEB, 1959.

. A pré-revolução brasileira. Rio de Janeiro: Fundo de Cultura, 1962.

. Subdesenvolvimento e estagnação na América Latina. Rio de Janeiro: Civilização Brasileira, 1966.

FURTADO explicou nosso atraso, diz economista. Folha de São Paulo. São Paulo, 28 nov. 2004, p. A 10.

GRAMSCI, Antonio. Cadernos do Cárcere. Edição e tradução de Carlos Nelson Coutinho; coedição de Luiz Sérgio Henriques e Marco Aurélio Nogueira. 3 ed. Rio de Janeiro: Civilização Brasileira, 2004, 6 v.

. Os intelectuais e a organização da cultura. 7 ed. Rio de Janeiro: Civilização Brasileira, 1989.

. Maquiavel, a política e o Estado Moderno. 2 ed. Rio de Janeiro: Civilização Brasileira, 1976.

. A questão meridional. Rio de Janeiro: Paz e Terra, 1987.

GTDN. Uma política de desenvolvimento econômico para o Nordeste. In: TAMER, Alberto. O mesmo Nordeste. São Paulo: Herder, 1968, pp. 173-232.

HIRSCHAMN, Albert. Politica econômica na América Latina. São Paulo: Fundo de Cultura, 1965.

HOLANDA, Nilson. Incentivos fiscais e desenvolvimento regional. Fortaleza: Banco do Nordeste do Brasil, 1975.

KALVAN, Fábio Ricardo. O lugar da nação: estudo da abordagem da nação no Dual-estruturalismo de Celso Furtado e nos estudos sobre a dependência de Fernando Henrique Cardoso. Dissertação de Mestrado apresentada ao Programa de Pós-Graduação em Sociologia da USP. São Paulo, 2000.

MACCIOCCHI, Maria-Antonietta. A favor de Gramsci. 2 ${ }^{\underline{a}}$ ed. Rio de Janeiro: Paz e Terra, 1977.

MARANHÃO, Sílvio. Estado e planejamento regional: A experiência do Nordeste brasileiro. In: . $A$ questão Nordeste. Rio de Janeiro: Paz e Terra, 1984, pp. 55-70.

MORAES, Reginaldo C. Correa. Planejamento: ditadura ou democracia? Tese de Doutorado apresentada ao Programa de Pós-Graduação em Filosofia da USP. São Paulo, 1987.

OLIVEIRA, Francisco. A economia brasileira: crítica à razão dualista. 4ae ed. Petrópolis: Vozes, 1981.

. A navegação venturosa. In: OLIVEIRA, Francisco (Org.). Celso Furtado. São Paulo: Ática, 1983, pp.

7-27. (Grandes Cientistas Sociais, 33).

Terra, 1993.

Elegia para uma re(li)giāo: Sudene, Nordeste, planejamento e conflito de classes. $6^{a}$ ed. Rio de Janeiro: Paz e

. Um republicano exemplar. In: BRESSER-PEREIRA, Luiz Carlos; REGO, José Marcio (Orgs.). A grande esperança em Celso Furtado. São Paulo: Editora 34, 2001, pp. 217-220.

PERRUCI, Gadiel. A formação histórica do Nordeste e a questão regional. In: MARANHÃO, Sílvio (Org.). A questão nordeste. Rio de Janeiro: Paz e Terra, 1984, pp. 55-70.

PORTELLI, Hugues. Gramsci e o bloco histórico. Rio de Janeiro: Paz e Terra, 1977.

PREBISCH, Raúl (1949). O desenvolvimento econômico da América Latina e alguns de seus problemas principais. In: BIELSCHOWSKY, Ricardo (Org.). Cinqüenta anos de pensamento na CEPAL. Rio de Janeiro: Record, 2000. 2 v, pp. 69-136.

PREBISCH, Raúl. Dinâmica do desenvolvimento latino-americano. Rio de Janeiro: Fundo de Cultura, 1964.

RIDENTI, Marcelo. Cultura e política: os anos 1960-1970 e sua herança. In: DELGADO, Lucília de Almeida Neves; FERREIRA, Jorge (Orgs.). O Brasil Republicano: o tempo da ditadura. Rio de Janeiro: Civilização Brasileira, 2003, pp. 133-166. 
ROBOCK, Stefan H. Desenvolvimento econômico regional: o nordeste brasileiro. Rio de Janeiro: Fundo de Cultura, 1964.

SANTOS, Maria Odete. Nação e mundialização no pensamento de Celso Furtado. Tese de Doutorado apresentada ao Programa de Pós-Graduação em História da Unicamp. Campinas, 1998.

SECCO, Lincoln. Gramsci e o Brasil. São Paulo: Cortez, 2002.

SILVEIRA, Rosa Maria Godoy. O regionalismo nordestino: existência e consciência da desigualdade regional. São Paulo: Moderna, 1984.

SOUZA, João Gonçalves de. O Nordeste brasileiro: uma experiência de desenvolvimento regional. Fortaleza: BNB, 1979.

\section{RESUMO}

Este artigo analisa a questão regional na interpretação de dois intelectuais do século XX: Antonio Gramsci e Celso Furtado. Na primeira parte, aborda o enfoque da questão do Mezzogiorno na Itália por Gramsci; na segunda, trata da leitura de Furtado acerca da questão do nordeste no Brasil. Na última parte, procede-se a um paralelo entre os dois autores, apontando semelhanças e diferenças entre suas interpretaçôes e projetos.

Palavras-chave: questão regional, Antonio Gramsci, Celso Furtado.

\section{ABSTRACT}

This article analyses the topic of regional difficulty in the interpretation of two intellectuals of 20th century: Antonio Gramsci and Celso Furtado. The first part is about Gramscis analysis of the Mezzogiorno problem in Italy; in the second part, it deals with Furtado's work on the Northeastern problem in Brazil. Lastly, the article makes a comparison between the two authors, pointing out similarities and differences over their interpretations and projects. Keywords: regional problem, Antonio Gramsci, Celso Furtado. 